\title{
Uji Ketahanan Salinitas Beberapa Varietas Jagung (Zea mays L.) Dengan Menggunakan Agen Seleksi NaCl
}

\author{
AMIRULLAH DACHLAN ${ }^{1}$, NURLINA KASIM ${ }^{1}$, A. KURNIA SARI ${ }^{1}$ \\ ${ }^{1}$ Jurusan Budidaya Pertanian, Fakultas Pertanian, Universitas Hasanuddin \\ Jl. Perintis Kemerdekaan Km.10 Makassar, 90245 \\ email: davarzharis@yahoo.co.id
}

\begin{abstract}
This study aims to determine the concentration of $\mathrm{NaCl}$ which can be used as maize resistance limit to salinity and to obtain varieties that are tolerant to salinity. This research was conducted in the form of an experiment with randomized design factorial using two factors in the group. As the first factor is the variety of Arjuna, Sukmaraga, Bhishma, Gumarang, Heroine Yellow, Pacakka, Anoman1, and LAMURU. The second factor is the concentration of $\mathrm{NaCl}$ with $0 \mathrm{~g} \mathrm{~L}^{-1}, 3 \mathrm{~g} \mathrm{~L}^{-1}, 4 \mathrm{~g} \mathrm{~L}^{-1}$, and 5 $\mathrm{g} \mathrm{L}^{-1}$. The results showed that the level of resistance of some maize varieties to salinity using $\mathrm{NaCl}$ produce varieties that have different resistance levels to high levels of salinity, there are varieties that can withstand the high $\mathrm{NaCl}$ concentration and some are only able to survive on a low $\mathrm{NaCl}$ concentration. The test results obtained sequentially showed varieties that are resistant to salinity is Pacakka. The concentration of $5 \mathrm{~g} \mathrm{~L}-1 \mathrm{NaCl}$ can not be used as a concentration limit for the grouping of maize resistance to salinity.
\end{abstract}

Keywords: Maize (Zea mays L.), NaCl, Salinity

\section{PENDAHULUAN}

Jagung (Zea mays L.) merupakan tanaman pangan yang sangat penting karena hingga kini, jagung merupakan makanan pengganti beras bagi sebagian penduduk Indonesia. Selain itu jagung juga merupakan komoditas strategis karena mempunyai pengaruh yang besar terhadap kestabilan ekonomi. Hal ini dipicu oleh semakin bertambahnya permintaan jagung akibat semakin meningkatnya kebutuhan dalam pembuatan bahan makanan, serta sebagai pakan ternak dan bahan baku industri. Selain itu produksi sampingan berupa batang, daun, dan klobot dapat juga dimanfaatkan sebagai mulsa organik ataupun bahan pupuk kompos. Seiring dengan semakin meningkatnya ilmu pengetahuan dan teknologi, tanaman jagung saat ini banyak dikembangkan sebagai penghasil energi, di mana jagung merupakan salah satu tanaman penghasil bioetanol dalam jumlah yang cukup besar.

Kebutuhan jagung tiap tahun mengalami peningkatan sebesar 10-15\% sehingga impor jagung pada tahun 2006 mencapai 1,6 juta ton, jauh lebih tinggi dibandingkan dengan impor jagung tahun 2005 yang mencapai 400.000 ton, dan diperkirakan semakin besar pada tahun-tahun berikutnya meskipun produksi ikut meningkat. Upaya untuk meningkatkan produksi jagung, terus-menerus dilakukan oleh pemerintah seiring dengan bertambahnya jumlah penduduk. Salah satu hambatan dalam peningkatan produksi jagung adalah semakin berkurangnya lahan-lahan subur yang sesuai dengan kondisi pertanaman jagung sebagai akibat terjadinya alih-fungsi lahan menjadi lahan kawasan industri dan pemukiman, sehingga lahan-lahan produktif untuk pertanian semakin berkurang. Depertemen Pertanian memperkirakan alih-fungsi lahan pertanian ke sektor non pertanian mencapai 47 ribu hektar per tahun (Nasution, 2006). Apabila lahan subur telah beralih fungsi untuk kebutuhan lain, maka pilihan lain adalah menggarap lahan-lahan marginal dengan berbagai permasalahan cekaman lingkungan.

Cekaman lingkungan merupakan faktor penghambat pertumbuhan tanaman. Di antara berbagai cekaman lingkungan, salinitas merupakan salah satu cekaman yang paling banyak dijumpai (Gedoan dkk, 2004). Di Indonesia terdapat sekitar 39,4 juta hektar tergolong lahan yang salin dan di Sulawesi 
Selatan terdapat kurang lebih 1 juta hektar lahan yang tidak dapat ditanami karena adanya masalah salinitas terutama di daerah-daerah pesisir pantai seperti Kabupaten Jeneponto, Pangkep, Bantaeng, Selayar, dan Barru. Salinitas semakin mendapat perhatian dalam pertanian, karena menyebabkan kondisi tercekam pada tanaman (Nugraheni dkk, 2003). Oleh karena itu, diperlukan varietas tahan terhadap kondisi salinitas yang tinggi sehingga lahan marginal diharapkan lebih kondusif dalam peningkatan produksi

Sejak tanaman jagung dikembangkan di Indonesia tercatat berbagai varietas telah dihasilkan baik varietas hibrida maupun varietas komposit yang berasal dari dalam negeri maupun hasil introduksi. Namun tidak semua varietas-varietas yang telah dikembangkan memiliki toleransi yang baik terhadap lingkungan yang stress terutama pada lahan yang salin.

Langkah awal untuk memperoleh varietas jagung toleran salin adalah melakukan uji ketahanan beberapa varietas yang ada untuk dinilai tingkat ketahanannya berdasarkan konsentrasi $\mathrm{NaCl}$ yang digunakan. Berdasarkan pengujian tersebut dapat ditentukan varietas yang memiliki ketahanan terbaik pada keadaan salinitas.

\section{METODE}

Persiapan media tanam. Media tanam yang digunakan pada penelitian ini ada 2 yaitu media tanam untuk penginduksian benih jagung terhadap $\mathrm{NaCl}$ yakni campuran media tanam pasir, tanah dan pupuk bokashi dengan perbandingan volume 1:1:1 dengan menggunakan talang dan media tanam pada tingkat pertumbuhan yakni campuran media tanam tanah, pasir, dan pupuk kandang sapi dengan perbandingan volume 2:1:1.

Setelah itu media tanam ini dicampur secara merata sesuai dengan perbandingan yang digunakan. Campuran media tanam tanah, pasir dan pupuk kandang sapi di masukkan ke dalam ember yang memuat tanah seberat $12 \mathrm{~kg}$.

Penanaman. Benih jagung dari 8 varietas sebelum ditanam terlebih dahulu direndam dengan menggunakan Dithane-45 selama 30 menit setelah itu dibilas dengan menggunakan air bersih, selanjutnya ditanam pada wadah berupa talang yang digunakan untuk menginduksi benih jagung dengan $\mathrm{NaCl}$ selama 2 minggu. Pemberian $\mathrm{NaCl}$ dilakukan pada awal penanaman sesuai dengan konsentrasi yang digunakan. Setelah 2 minggu bibit jagung yang telah tumbuh dengan baik dipindahkan pada ember yang telah berisi campuran media tanam tanah, pasir, dan pupuk kandang sapi dengan perbandingan volume $2: 1: 1$. setiap ember terdiri dari 2-3 bibit jagung. Pemberian $\mathrm{NaCl}$ dilakukan sebanyak 2 kali yakni pada tanaman berumur 10 hari setelah tanam (HST) dan pada 35 HST. Pemberian $\mathrm{NaCl}$ terlebih dahulu dilakukan dengan melarutkan $\mathrm{NaCl}$ sesuai dengan konsentrasi yang digunakan ke dalam air sebanyak $1000 \mathrm{~mL}$. Setelah itu campuran $\mathrm{NaCl}$ dan air yang telah larut diberikan ke tanaman jagung sesuai dengan perlakuan dengan cara penyiraman.

Pemeliharaan. Pemeliharaan dilakukan dengan penyiraman, penjarangan, pemupukan dan penyiangan. Penyiraman dilakukan setiap hari sebanyak 1 kali sehari. Penyiraman tanaman dilakukan berdasarkan kapasitas lapang, di mana volume air yang diberikan disesuaikan dengan yang dibutuhkan oleh tanaman. Penjarangan dilakukan dengan mencabut tanaman yang tumbuhnya kurang baik dengan menyisakan 1 tanaman setiap ember. Pemupukan dilakukan dengan menggunakan pupuk urea sebanyak $12 \mathrm{~g}$ per tanaman, TSP $12 \mathrm{~g}$ per tanaman dan $\mathrm{KCl} 0,03$ $\mathrm{g}$ per tanaman yang diberikan pada saat tanaman berumur 1 MST. Penyiangan dilakukan secara intensif secara manual dengan menghilangkan gulma-gulma yang tumbuh di sekitar tanaman jagung.

Pengamatan dan Analisis. Komponen pengamatan dan analisis yang digunakan dalam penelitian ini antara lain panjang akar, tinggi tanaman, jumlah daun, diameter batang 2, 4, 6, dan 8 minggu setelah tanam (MST), umur berbunga jantan dan betina, umur panen, jumlah tongkol, dan bobot brangkasan tanaman. 


\section{HASIL}

Tabel 1. Rata-rata panjang akar $(\mathrm{cm})$ tanaman jagung pada berbagai varietas dan konsentrasi $\mathrm{NaCl}$ pada umur 2 MSP

\begin{tabular}{|c|c|c|c|c|c|c|}
\hline \multirow{2}{*}{ Varietas } & \multicolumn{4}{|c|}{ Konsentrasi $\mathrm{NaCl}\left(\mathrm{g} \mathrm{L}^{-1}\right)$} & \multirow{2}{*}{ Rata-rata } & \multirow{2}{*}{$\mathrm{NP} \mathrm{UJBD}_{0,01}$} \\
\hline & $0\left(\mathrm{k}_{0}\right)$ & $3\left(\mathrm{k}_{1}\right)$ & $4\left(\mathrm{k}_{2}\right)$ & $5\left(k_{3}\right)$ & & \\
\hline Arjuna $\left(\mathrm{v}_{1}\right)$ & 31,57 & 18,39 & 18,38 & 18,30 & $21,66^{\mathrm{b}}$ & 3,93 \\
\hline Sukmaraga $\left(\mathrm{v}_{2}\right)$ & 28,91 & 22,41 & 21,99 & 19,02 & $23,09^{\mathrm{b}}$ & 4,12 \\
\hline $\operatorname{Bisma}\left(v_{3}\right)$ & 27,31 & 24,57 & 20,61 & 18,31 & $22,70^{\mathrm{b}}$ & 4,24 \\
\hline Gumarang $\left(\mathrm{v}_{4}\right)$ & 27,51 & 26,38 & 21,41 & 18,73 & $23,51^{\mathrm{b}}$ & 4,33 \\
\hline Srikandi Kuning ( $\mathrm{v}_{5}$ ) & 30,62 & 29,74 & 27,63 & 24,17 & $28,04^{\mathrm{a}}$ & 4,39 \\
\hline Pacakka ( $\left.\mathrm{v}_{6}\right)$ & 27,91 & 25,77 & 21,15 & 20,21 & $23,76^{\mathrm{b}}$ & 4,45 \\
\hline Anoman-I $\left(\mathrm{v}_{7}\right)$ & 24,26 & 23,34 & 23,11 & 20,85 & $22,89^{\mathrm{b}}$ & 4,50 \\
\hline Lamuru $\left(\mathrm{v}_{8}\right)$ & 28,21 & 27,09 & 23,01 & 22,47 & $25,19^{\mathrm{ab}}$ & \\
\hline Rata-rata & $28,29^{\mathrm{a}}$ & $24,71^{\mathrm{b}}$ & $22,16^{\mathrm{bc}}$ & $20,26^{\mathrm{c}}$ & & \\
\hline $\mathrm{NP} \mathrm{BNT}_{0,01}$ & 2,80 & & & & & \\
\hline
\end{tabular}

Keterangan: Angka-angka yang masih diikuti oleh huruf yang sama berarti tidak berbeda nyata pada taraf uji $\mathrm{UJBD}_{\alpha=0,05}$ pada baris serta uji taraf uji $\mathrm{BNT}_{\alpha=0,01}$ pada kolom

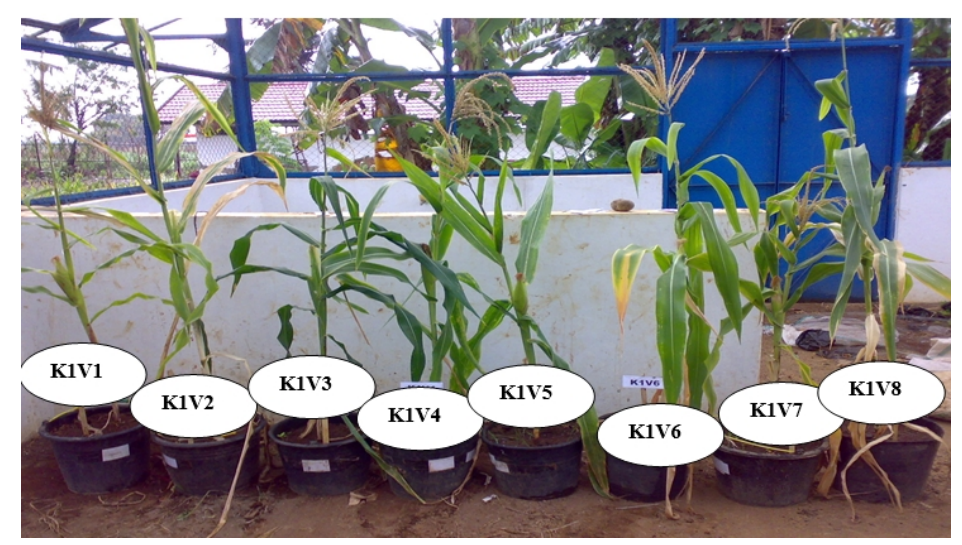

Gambar 1. Pertumbuhan tanaman jagung varietas Arjuna $\left(\mathrm{v}_{1}\right)$, Sukmaraga $\left(\mathrm{v}_{2}\right)$, Bisma $\left(\mathrm{v}_{3}\right)$, Gumarang $\left(\mathrm{v}_{4}\right)$, Srikandi Kuning ( $\left.\mathrm{v}_{5}\right)$, Pacakka ( $\left.\mathrm{v}_{6}\right)$, Anoman-1 ( $\left.\mathrm{v}_{7}\right)$, dan Lamuru ( $\left.\mathrm{v}_{8}\right)$ dengan pemberian $3 \mathrm{~g} \mathrm{~L}^{-1}$ $\mathrm{NaCl}$.

Tabel 2. Rata-rata tinggi tanaman $(\mathrm{cm})$ jagung pada berbagai varietas dan konsentrasi $\mathrm{NaCl}$ pada umur 2, 6 , 8, MST

\begin{tabular}{|c|c|c|c|c|c|}
\hline \multirow{2}{*}{ Varietas } & \multirow{2}{*}{ Umur } & \multicolumn{4}{|c|}{ Konsentrasi $\mathrm{NaCl}\left(\mathrm{g} \mathrm{L}^{-1}\right)$} \\
\hline & & $0\left(\mathrm{k}_{0}\right)$ & $3\left(\mathrm{k}_{1}\right)$ & $4\left(\mathrm{k}_{2}\right)$ & $5\left(\mathrm{k}_{3}\right)$ \\
\hline Rata-rata & \multirow{2}{*}{2} & $154,64^{\mathrm{a}}$ & $142,40^{\mathrm{ab}}$ & $142,29^{\mathrm{ab}}$ & $135,60^{\mathrm{b}}$ \\
\hline $\mathrm{NP} \mathrm{BNT}_{0,01}$ & & 12,84 & & & \\
\hline Rata-rata & \multirow{2}{*}{6} & $162,00^{\mathrm{a}}$ & $149,86^{\mathrm{ab}}$ & $149,73^{\mathrm{ab}}$ & $139,57^{b}$ \\
\hline $\mathrm{NP} \mathrm{BNT}_{0,01}$ & & 13,71 & & & \\
\hline Rata-rata & \multirow{2}{*}{8} & $168,90^{\mathrm{a}}$ & $157,82^{\mathrm{ab}}$ & $149,22^{\mathrm{bc}}$ & $143,19^{\mathrm{c}}$ \\
\hline $\mathrm{NP} \mathrm{BNT}_{0,01}$ & & 13,10 & & & \\
\hline
\end{tabular}

Keterangan: Angka-angka yang masih diikuti oleh huruf yang sama berarti tidak berbeda nyata pada taraf uji $\mathrm{UJBD}_{\alpha=0,05}$ pada baris serta uji taraf uji $\mathrm{BNT}_{\alpha=0,01}$ pada kolom 
Tabel 3. Rata-rata jumlah daun (helai) tanaman jagung pada berbagai varietas dan konsentrasi $\mathrm{NaCl}$ pada umur 4 MST

\begin{tabular}{|c|c|c|c|c|c|}
\hline \multirow{2}{*}{ Varietas } & \multirow[t]{2}{*}{ Umur } & \multicolumn{4}{|c|}{ Konsentrasi $\mathrm{NaCl}\left(\mathrm{g} \mathrm{L}^{-1}\right)$} \\
\hline & & $0\left(\mathrm{k}_{0}\right)$ & $3\left(\mathrm{k}_{1}\right)$ & $4\left(\mathrm{k}_{2}\right)$ & $5\left(\mathrm{k}_{3}\right)$ \\
\hline Rata-rata & \multirow{2}{*}{2} & $13,96^{\mathrm{a}}$ & $13,67^{\mathrm{a}}$ & $13,04^{\mathrm{ab}}$ & $12,42^{\mathrm{ab}}$ \\
\hline $\mathrm{NP} \mathrm{BNT}_{0,01}$ & & 1,05 & & & \\
\hline Rata-rata & \multirow{2}{*}{6} & $14,29^{\mathrm{a}}$ & $13,46^{\mathrm{a}}$ & $11,63^{b}$ & $11,79^{b}$ \\
\hline $\mathrm{NP} \mathrm{BNT}_{0,01}$ & & 0,98 & & & \\
\hline Rata-rata & \multirow{2}{*}{8} & $13,75^{\mathrm{a}}$ & $12,25^{\mathrm{b}}$ & $9,79^{\mathrm{c}}$ & $9,00^{\mathrm{c}}$ \\
\hline $\mathrm{NP} \mathrm{BNT}_{0,01}$ & & 0,83 & & & \\
\hline
\end{tabular}

Keterangan: Angka-angka yang masih diikuti oleh huruf yang sama berarti tidak berbeda nyata pada taraf uji $\mathrm{UJBD}_{\alpha=0,05}$ pada baris serta uji taraf uji $\mathrm{BNT}_{\alpha=0,01}$ pada kolom

Tabel 4. Rata-rata diameter batang $(\mathrm{cm})$ tanaman jagung pada berbagai varietas dan konsentrasi $\mathrm{NaCl}$ pada umur 2 MST

\begin{tabular}{|c|c|c|c|c|}
\hline \multirow{2}{*}{ Varietas } & \multicolumn{4}{|c|}{ Konsentrasi $\mathrm{NaCl}\left(\mathrm{g} \mathrm{L}^{-1}\right)$} \\
\hline & $0\left(\mathrm{k}_{0}\right)$ & $3\left(\mathrm{k}_{1}\right)$ & $4\left(\mathrm{k}_{2}\right)$ & $4\left(\mathrm{k}_{3}\right)$ \\
\hline Rata-rata & $1,50^{\mathrm{a}}$ & $1,41^{\mathrm{ab}}$ & $1,32^{b}$ & $1,32^{\mathrm{b}}$ \\
\hline $\mathrm{NP} \mathrm{BNT}_{0,05}$ & 0,13 & & & \\
\hline Rata-rata & $1,44^{\mathrm{a}}$ & $1,39^{\mathrm{ab}}$ & $1,34^{\mathrm{ab}}$ & $1,29^{b}$ \\
\hline $\mathrm{NP} \mathrm{BNT}_{0,05}$ & 0,11 & & & \\
\hline Rata-rata & $1,36^{\mathrm{a}}$ & $1,28^{\mathrm{ab}}$ & $1,24^{b}$ & $1,20^{\mathrm{b}}$ \\
\hline $\mathrm{NP} \mathrm{BNT}_{0,05}$ & 0,09 & & & \\
\hline Rata-rata & $1,35^{\mathrm{a}}$ & $1,24^{\mathrm{ab}}$ & $1,16^{\mathrm{bc}}$ & $1,07^{\mathrm{c}}$ \\
\hline $\mathrm{NP} \mathrm{BNT}_{0,05}$ & 0,13 & & & \\
\hline
\end{tabular}

Keterangan: Angka-angka yang masih diikuti oleh huruf yang sama berarti tidak berbeda nyata pada taraf uji $\mathrm{UJBD}_{\alpha=0,05}$ pada baris serta uji taraf uji $\mathrm{BNT}_{\alpha=0,01}$ pada kolom

Tabel 5. Rata-rata umur berbunga jantan (hari) tanaman jagung pada berbagai varietas dan konsentrasi $\mathrm{NaCl}$

\begin{tabular}{|c|c|c|c|c|c|c|}
\hline \multirow{2}{*}{ Varietas } & \multicolumn{4}{|c|}{ Konsentrasi $\mathrm{NaCl}\left(\mathrm{g} \mathrm{L}^{-1}\right)$} & \multirow{2}{*}{ Rata-rata } & \multirow{2}{*}{ NP UJBD ${ }_{0,01}$} \\
\hline & $0\left(\mathrm{k}_{0}\right)$ & $6\left(\mathrm{k}_{1}\right)$ & $8\left(\mathrm{k}_{2}\right)$ & $10\left(\mathrm{k}_{3}\right)$ & & \\
\hline Arjuna $\left(\mathrm{v}_{1}\right)$ & 56,67 & 57,00 & 58,00 & 55,00 & $56,67^{\mathrm{abc}}$ & 2,88 \\
\hline Sukmaraga $\left(\mathrm{v}_{2}\right)$ & 58,67 & 60,00 & 59,00 & 60,33 & $59,50^{\mathrm{a}}$ & 3,02 \\
\hline Bisma (v3) & 57,67 & 52,67 & 54,67 & 56,00 & $55,25^{\mathrm{bc}}$ & 3,10 \\
\hline Gumarang $\left(\mathrm{v}_{4}\right)$ & 55,00 & 51,67 & 56,33 & 54,67 & $54,42^{\mathrm{c}}$ & 3,17 \\
\hline Srikandi Kuning ( $\mathrm{v}_{5}$ ) & 57,00 & 57,00 & 60,00 & 58,67 & $58,17^{\mathrm{ab}}$ & 3,21 \\
\hline Pacakka ( $\left.\mathrm{v}_{6}\right)$ & 55,67 & 55,67 & 59,00 & 60,33 & $57,67^{\mathrm{ab}}$ & 3,26 \\
\hline Anoman-I ( $\left.\mathrm{v}_{7}\right)$ & 56,67 & 58,00 & 57,67 & 55,00 & $56,83^{\mathrm{abc}}$ & 3,29 \\
\hline Lamuru ( $\left.\mathrm{v}_{8}\right)$ & 57,33 & 58,33 & 52,33 & 56,67 & $56,17^{\mathrm{bc}}$ & \\
\hline
\end{tabular}

Keterangan: Angka-angka yang masih diikuti oleh huruf yang sama berarti tidak berbeda nyata pada taraf uji $\mathrm{UJBD}_{\alpha=0,05}$ pada baris serta uji taraf uji $\mathrm{BNT}_{\alpha=0,01}$ pada kolom

Tabel 6. Rata-rata umur berbunga betina (hari) tanaman jagung pada berbagai varietas dan konsentrasi $\mathrm{NaCl}$

\begin{tabular}{|c|c|c|c|c|c|c|}
\hline \multirow{2}{*}{ Varietas } & \multicolumn{4}{|c|}{ Konsentrasi $\mathrm{NaCl}\left(\mathrm{g} \mathrm{L}^{-1}\right)$} & \multirow{2}{*}{ Rata-rata } & \multirow{2}{*}{$\mathrm{NP} \mathrm{UJBD}_{0,01}$} \\
\hline & $0\left(\mathrm{k}_{0}\right)$ & $3\left(\mathrm{k}_{1}\right)$ & $4\left(\mathrm{k}_{2}\right)$ & $5\left(\mathrm{k}_{3}\right)$ & & \\
\hline Arjuna $\left(\mathrm{v}_{1}\right)$ & 62,00 & 65,67 & 67,00 & 69,00 & $65,92^{\mathrm{c}}$ & 2,83 \\
\hline Sukmaraga $\left(\mathrm{v}_{2}\right)$ & 65,00 & 65,33 & 69,67 & 73,33 & $68,33^{\mathrm{abc}}$ & 2,97 \\
\hline
\end{tabular}




\begin{tabular}{|c|c|c|c|c|c|c|}
\hline $\operatorname{Bisma}\left(v_{3}\right)$ & 63,33 & 66,33 & 68,67 & 63,33 & $65,42^{\mathrm{c}}$ & 3,06 \\
\hline Gumarang $\left(\mathrm{v}_{4}\right)$ & 64,00 & 65,33 & 66,00 & 67,33 & $65,67^{\mathrm{c}}$ & 3,13 \\
\hline Srikandi Kuning ( $\mathrm{v}_{5}$ ) & 67,33 & 67,67 & 69,33 & 75,00 & $69,83^{\mathrm{ab}}$ & 3,16 \\
\hline Pacakka ( $\left.\mathrm{v}_{6}\right)$ & 66,33 & 66,67 & 67,67 & 67,67 & $67,08^{\mathrm{bc}}$ & 3,21 \\
\hline Anoman-I ( $\left.\mathrm{v}_{7}\right)$ & 66,67 & 69,00 & 73,00 & 75,00 & $70,92^{\mathrm{a}}$ & 3,24 \\
\hline Lamuru ( $\left.\mathrm{v}_{8}\right)$ & 67,33 & 68,67 & 71,33 & 75,00 & $70,58^{\mathrm{a}}$ & \\
\hline Rata-rata & $65,25^{\mathrm{a}}$ & $66,83^{\mathrm{a}}$ & $69,08^{\mathrm{b}}$ & $70,71^{b}$ & & \\
\hline
\end{tabular}

Keterangan: Angka-angka yang masih diikuti oleh huruf yang sama berarti tidak berbeda nyata pada taraf uji $\mathrm{UJBD}_{\alpha=0,05}$ pada baris serta uji taraf uji $\mathrm{BNT}_{\alpha=0,01}$ pada kolom

Tabel 7. Rata-rata umur panen (hari) tanaman jagung pada berbagai varietas dan konsentrasi $\mathrm{NaCl}$

\begin{tabular}{|c|c|c|c|c|c|c|}
\hline \multirow{2}{*}{ Varietas } & \multicolumn{4}{|c|}{ Konsentrasi $\mathrm{NaCl}\left(\mathrm{g} \mathrm{L}^{-1}\right)$} & \multirow{2}{*}{ Rata-rata } & \multirow{2}{*}{ NP $\mathrm{UJBD}_{0,01}$} \\
\hline & $0\left(\mathrm{k}_{0}\right)$ & $3\left(\mathrm{k}_{1}\right)$ & $4\left(\mathrm{k}_{2}\right)$ & $5\left(\mathrm{k}_{3}\right)$ & & \\
\hline Arjuna $\left(\mathrm{v}_{1}\right)$ & 79,67 & 82,00 & 95,00 & 95,00 & $87,92^{\text {cd }}$ & 5,08 \\
\hline Sukmaraga $\left(\mathrm{v}_{2}\right)$ & 77,33 & 84,33 & 94,33 & 95,00 & $87,75^{\mathrm{cd}}$ & 5,34 \\
\hline $\operatorname{Bisma}\left(v_{3}\right)$ & 80,33 & 85,33 & 85,33 & 86,00 & $84,25^{\mathrm{d}}$ & 5,49 \\
\hline Gumarang $\left(\mathrm{v}_{4}\right)$ & 87,33 & 88,67 & 89,33 & 89,33 & $88,67^{\mathrm{cd}}$ & 5,61 \\
\hline Srikandi Kuning ( $\left.\mathrm{v}_{5}\right)$ & 87,00 & 89,00 & 89,00 & 93,33 & $89,58^{\text {bcd }}$ & 5,68 \\
\hline Pacakka $\left(\mathrm{v}_{6}\right)$ & 94,33 & 94,67 & 95,00 & 95,00 & $94,75^{\mathrm{ab}}$ & 5,76 \\
\hline Anoman-I ( $\left.\mathrm{v}_{7}\right)$ & 86,33 & 86,33 & 92,67 & 100,00 & $91,33^{\mathrm{abc}}$ & 5,82 \\
\hline Lamuru $\left(\mathrm{v}_{8}\right)$ & 92,67 & 93,33 & 95,00 & 100,00 & $95,25^{\mathrm{a}}$ & \\
\hline Rata-rata & $85,63^{\mathrm{a}}$ & $87,96^{\mathrm{a}}$ & $91,96^{\mathrm{b}}$ & $94,21^{\mathrm{b}}$ & & \\
\hline
\end{tabular}

$\mathrm{NP} \mathrm{BNT}_{0,01} \quad 3,62$

Keterangan: Angka-angka yang masih diikuti oleh huruf yang sama berarti tidak berbeda nyata pada taraf uji $\mathrm{UJBD}_{\alpha=0,05}$ pada baris serta uji taraf uji $\mathrm{BNT}_{\alpha=0,01}$ pada kolom

Tabel 8. Rata-rata jumlah tongkol (buah) tanaman jagung pada berbagai varietas dan konsentrasi $\mathrm{NaCl}$

\begin{tabular}{|c|c|c|c|c|}
\hline \multirow{2}{*}{ Varietas } & \multicolumn{4}{|c|}{ Konsentrasi $\mathrm{NaCl}\left(\mathrm{gL}^{-1}\right)$} \\
\hline & $0\left(\mathrm{k}_{0}\right)$ & $6\left(\mathrm{k}_{1}\right)$ & $8\left(k_{2}\right)$ & $10\left(\mathrm{k}_{3}\right)$ \\
\hline \multirow{3}{*}{ Arjuna $\left(\mathrm{v}_{1}\right)$} & 3,00 & 3,00 & 3,00 & 3,00 \\
\hline & $1,22^{\mathrm{b}}$ & $1,22^{b}$ & $1,22^{b}$ & $1,11^{\mathrm{b}}$ \\
\hline & 4,00 & 3,00 & 3,00 & 0,00 \\
\hline \multirow[t]{2}{*}{ Sukmaraga $\left(\mathrm{v}_{2}\right)$} & $1,34^{\mathrm{b}}$ & $1,22^{\mathrm{b}}$ & $1,22^{\mathrm{b}}$ & $0,70^{\mathrm{c}}$ \\
\hline & 4,00 & 3,00 & 3,00 & 3,00 \\
\hline \multirow[t]{2}{*}{$\operatorname{Bisma~}\left(v_{3}\right)$} & $1,34^{\mathrm{b}}$ & $1,22^{\mathrm{b}}$ & $1,22^{b}$ & $1,22^{\mathrm{b}}$ \\
\hline & 4,00 & 3,00 & 3,00 & 3,00 \\
\hline \multirow{2}{*}{ Gumarang ( $\left.\mathrm{v}_{4}\right)$} & $1,34^{\mathrm{b}}$ & $1,22^{\mathrm{b}}$ & $1,22^{\mathrm{b}}$ & $1,22^{\mathrm{b}}$ \\
\hline & 3,00 & 3,00 & 3,00 & 3,00 \\
\hline \multirow[t]{2}{*}{ Srikandi Kuning ( $\mathrm{v}_{5}$ ) } & $1,22^{\mathrm{b}}$ & $1,22^{\mathrm{b}}$ & $1,22^{\mathrm{b}}$ & $1,22^{\mathrm{b}}$ \\
\hline & 6,00 & 3,00 & 3,00 & 3,00 \\
\hline \multirow[t]{2}{*}{ Pacakka (v6) } & $1,58^{\mathrm{a}}$ & $1,22^{\mathrm{b}}$ & $1,22^{\mathrm{b}}$ & $1,22^{\mathrm{b}}$ \\
\hline & 3,00 & 3,00 & 0,00 & 0,00 \\
\hline \multirow[t]{2}{*}{ Anoman-I ( $\left.\mathrm{v}_{7}\right)$} & $1,22^{\mathrm{b}}$ & $1,22^{\mathrm{b}}$ & $0,70^{\mathrm{c}}$ & $0,70^{\mathrm{c}}$ \\
\hline & 3,00 & 3,00 & 1,00 & 0,00 \\
\hline Lamuru ( $\left.\mathrm{v}_{8}\right)$ & $1,22^{\mathrm{b}}$ & $1,22^{\mathrm{b}}$ & $0,87^{\mathrm{c}}$ & $0,70^{\mathrm{c}}$ \\
\hline
\end{tabular}

Keterangan : Angka-angka yang masih diikuti oleh huruf yang sama berarti tidak berbeda nyata pada taraf uji $\mathrm{UJBD}_{\alpha=0,01}$. (angka-angka yang tidak diikuti oleh huruf adalah angka-angka sebelum transformasi $\sqrt{X+0,5}$ ) 
Tabel 9. Rata-rata berat berangkasan (g) tanaman jagung pada berbagai varietas dan konsentrasi $\mathrm{NaCl}$

\begin{tabular}{|c|c|c|c|c|c|c|}
\hline \multirow{2}{*}{ Varietas } & \multicolumn{4}{|c|}{ Konsentrasi $\mathrm{NaCl}\left(\mathrm{g} \mathrm{L}^{-1}\right)$} & \multirow{2}{*}{ Rata-rata } & \multirow{2}{*}{$\mathrm{NP} \mathrm{UJBD}_{0,0}$} \\
\hline & $0\left(\mathrm{k}_{0}\right)$ & $3\left(\mathrm{k}_{1}\right)$ & $4\left(\mathrm{k}_{2}\right)$ & $5\left(\mathrm{k}_{3}\right)$ & & \\
\hline$\overline{\text { Arjuna }\left(\mathrm{v}_{1}\right)}$ & 76,67 & 71,67 & 63,33 & 61,67 & $68,33^{\text {bc }}$ & 13,22 \\
\hline Sukmaraga $\left(\mathrm{v}_{2}\right)$ & 101,67 & 91,67 & 80,00 & 80,00 & $88,33^{\mathrm{a}}$ & 13,88 \\
\hline $\operatorname{Bisma}\left(v_{3}\right)$ & 86,67 & 73,33 & 68,33 & 65,00 & $73,33^{\mathrm{b}}$ & 14,27 \\
\hline Gumarang $\left(\mathrm{v}_{4}\right)$ & 75,00 & 65,00 & 56,67 & 53,33 & $62,50^{\mathrm{bc}}$ & 14,59 \\
\hline Srikandi Kuning $\left(\mathrm{v}_{5}\right)$ & 76,67 & 76,67 & 75,00 & 75,00 & $75,83^{\mathrm{ab}}$ & 14,76 \\
\hline Pacakka $\left(\mathrm{v}_{6}\right)$ & 86,67 & 76,67 & 75,00 & 68,33 & $76,67^{\mathrm{ab}}$ & 14,98 \\
\hline Anoman-I ( $\left.\mathrm{v}_{7}\right)$ & 61,67 & 57,67 & 51,00 & 50,00 & $55,08^{\mathrm{c}}$ & 15,13 \\
\hline Lamuru $\left(\mathrm{v}_{8}\right)$ & 101,67 & 61,67 & 58,33 & 55,00 & $69,17^{\mathrm{bc}}$ & \\
\hline Rata-rata & $83,33^{\mathrm{a}}$ & $71,79^{b}$ & $65,96^{\mathrm{b}}$ & $63,54^{\mathrm{b}}$ & & \\
\hline $\mathrm{NP} \mathrm{BNT}_{0,01}$ & 9,41 & & & & & \\
\hline
\end{tabular}

Keterangan: Angka-angka yang masih diikuti oleh huruf yang sama berarti tidak berbeda nyata pada taraf uji $\mathrm{UJBD}_{\alpha=0,05}$ pada baris serta uji taraf uji $\mathrm{BNT}_{\alpha=0,01}$ pada kolom

\section{PEMBAHASAN}

Konsentrasi NaCl. Hasil analisis statistik pada pengujian ketahanan tanaman jagung dengan pemberian $\mathrm{NaCl}$ menunjukkan bahwa respon panjang akar (Tabel 1) semakin menurun dengan semakin meningkatnya konsentrasi $\mathrm{NaCl}$ yang diberikan pada media tumbuh tanaman, dengan tingkat penghambatan terhadap pertumbuhan yang berbeda-beda. Penghambatan terhadap panjang akar nampak jelas pada konsentrasi $\mathrm{NaCl} 5 \mathrm{~g} \mathrm{~L}^{-1}$ dibandingkan dengan tanpa pemberian $\mathrm{NaCl}$. Penghambatan proses terbentuknya akar diduga sebagai akibat terjadinya akumulasi garam $\mathrm{NaCl}$ pada lingkungan perakaran. Akumulasi garam yang semakin tinggi akan menghambat pertumbuhan perakaran yang semakin kuat. Penurunan panjang akar disebabkan tanaman mengalami cekaman osmotik akibat meningkatnya konsentrasi garam-garam terlarut sehingga pembelahan dan pembentangan sel pada ujung-ujung akar terhambat, keadaan ini akan mengurangi jumlah total akar yang terbentuk pada setiap perlakuan sehingga secara keseluruhan volume akar akan menurun. Adanya cekaman osmotik akibat pengaruh $\mathrm{NaCl}$ pada media tumbuh menyebabkan sel yang sedang tumbuh menjadi kekurangan air. Pada kondisi kekurangan air maka pembesaran sel akan menurun aibat rendahnya turgiditas sel. Jumin (2002), menyatakan bahwa hilangnya turgiditas sel dapat menghentikan pertumbuhan sel (penggandaan dan pembesaran sel) sehingga menghambat pertumbuhan tanaman.

Hasil analisis statistik pada pengujian ketahanan tanaman jagung dengan pemberian $\mathrm{NaCl}$ menunjukkan bahwa respon pertumbuhan (Tabel 2) semakin menurun dengan semakin meningkatnya konsentrasi $\mathrm{NaCl}$ yang diberikan pada media tumbuh tanaman, dengan tingkat penghambatan terhadap pertumbuhan yang berbeda-beda. Penghambatan terhadap tinggi tanaman misalnya, nampak jelas pada umur 8 MST. Perbedaan yang jelas antara konsentrasi $0 \mathrm{~g} \mathrm{~L}^{-}$ 1 dengan $4 \mathrm{~g} \mathrm{~L}^{-1}$ baru nampak pada umur 8 MST. Berbeda halnya dengan variabel pengamatan jumlah daun dan diameter batang respon penurunan pada konsentrasi yang lebih tinggi cukup nyata terlihat pada awal-awal pengukuran dibandingkan konsentrasi $\mathrm{NaCl}$ yang lebih rendah.

Makin lama pemaparan pada media salin yang digunakan maka tinggi tanaman semakin menurun (Tabel 2). Penurunan tinggi tanaman diduga disebabkan oleh adanya pengaruh cekaman osmotik yang menyebabkan tanaman sulit menyerap air dan pengaruh racun dari ion $\mathrm{Na}$ dan $\mathrm{Cl}$ akibat pemberian $\mathrm{NaCl}$, sehingga pembelahan dan pembesaran sel terhambat dan tanaman akan tumbuh kerdil. Jumlah daun dan diameter batang (Tabel 3 dan 4) menunjukkan penurunan yang nyata pada awal pengukuran 
disebabkan oleh terlarutnya garam-garam sehingga menurunkan potensial air yang berakibat tanaman sulit untuk menyerap air dan proses pertumbuhannya tidak normal sebagai contoh pembentukan dan pembesaran sel-sel yang mempengaruhi pertumbuhan batang terhambat selain itu cepatnya penuaan daun sehingga terjadi pengurangan jumlah daun. Beberapa peneliti mengemukaan bahwa pengaruh yang paling penting dari kekeringan adalah pengurangan fotosintesis yang diakibatkan oleh penurunan luas permukaan daun dan terlalu awalnya terjadi penuaan daun. Hal ini diduga berkaitan dengan penurunan turgor dan potensial air tanaman. Biasanya penurunan turgor dan potensial air tanaman selalu diikuti dengan penutupan stomata sehingga menurunkan pertumbuhan tanaman. Bahkan jika potensial air daun mencapai -15 Bar daun akan pucat dan menggulung karena berkurangnya turgiditas sel daun sehingga memperkecil luas dan jumlah daun. Keadaan tersebut disebabkan oleh adanya molekul $\mathrm{NaCl}$ yang mengalami ionisasi menjadi $\mathrm{Na}^{+}$dan $\mathrm{Cl}^{-}$ sehingga terjadi peningkatan salinitas pada media tumbuh yang menginduksi terjadinya stress ion mengakibatkan pertumbuhan dan perkembangan sel-sel tanaman terhambat (Teare dan Peet, 1983).

Hasil analisis statistik selanjutnya menunjukkan produksi tanaman jagung dengan pemberian $\mathrm{NaCl}$ menunjukkan pula keadaan yang tidak berbeda dengan keadaan pada tingkat pertumbuhan. Adanya $\mathrm{NaCl}$ dalam media tumbuh dengan konsentrasi yang semakin meningkat akan berpengaruh pada proses-proses fisiologis tanaman seperti fotosintesis. Pemberian $\mathrm{NaCl}$ yang dapat menginduksi cekaman air (kekeringan) dapat menurunkan laju fotosintesis oleh adanya tiga kombinasi yaitu menutupnya stomata, meningkatnya resistensi mesofil dan menurunnya efesiensi sistem fotosintesis. Menurut Blum (1988), pengaruh salinitas terhadap fotosintesis tanaman paling sedikit dapat dibagi dalam tiga kategori: (1) mempengaruhi sifat pertumbuhan daun, yang kemudian berpengaruh terhadap fotosintesis, (2) mempengaruhi resistensi stomata terhadap difusi $\mathrm{CO}_{2}$ dan (3) berpengaruh terhadap reaksi-reaksi biokimia dalam fotosintesis. Hal demikian menyebabkan rendahnya laju fotosintesis terutama pada tanaman yang ditanam pada konsentrasi $\mathrm{NaCl}$ yang lebih tinggi.

Peningkatan konsentrasi $\mathrm{NaCl}$ pada media tumbuh secara umum akan mempengaruhi pertumbuhan dan produksi tanaman yang akan diperoleh. Hasil yang diperoleh menujukkan bahwa dengan semakin bertambahnya konsentrasi $\mathrm{NaCl}$ maka diperoleh bobot brangkasan yang semakin kecil (Tabel 9). Perbedaan tersebut sangat signifikan pada tanaman yang ditumbuhkan dalam media dengan penambahan $\mathrm{NaCl}$ dibandingkan dengan tanpa $\mathrm{NaCl}$. Penurunan berat brangkasan terjadi dengan bertambahnya konsentrasi $\mathrm{NaCl}$. Bobot brangkasan tanaman merupakan indikator pertumbuhan tanaman secara keseluruhan, sehingga terdapat kecenderungan bila bobot brangkasan yang dihasilkan tanaman semakin besar berarti tanaman mengalami pertumbuhan yang baik selama hidupnya. Penurunan bobot brangkasan merupakan akumulasi dari gangguan-gangguan pertumbuhan akibat pengaruh $\mathrm{NaCl}$. Sitompul dan Bambang (1995), menyatakan bahwa bobot brangkasan tanaman merupakan ukuran yang paling sering digunakan untuk menggambarkan dan mempelajari pertumbuhan tanaman. Ini didasarkan atas kenyataan bahwa taksiran tersebut relatif mudah diukur dan merupakan integrasi dari hampir semua peristiwa yang dialami tanaman sebelumnya, sehingga komponen ini merupakan indikator pertumbuhan yang paling representatif apabila tujuan utamanya adalah mendapatkan penampilan keseluruhan tanaman atau suatu organ tertentu.

Varietas. Terdapat respon yang berbeda dari masing-masing varietas (Gambar 1). Varietas Bisma menghasilkan umur berbunga betina dan umur panen tercepat. Varietas Srikandi Kuning menghasilkan jumlah daun terbanyak. Varietas Pacakka menghasilkan tanaman tertinggi, varietas Sukmaraga menghasilkan diameter batang terlebar dan brangkasan terberat dan varietas Gumarang menghasilkan umur berbunga jantan tercepat. 
Adanya perbedaan penampilan tanaman (fenotipe) merupakan akibat dari pengaruh genetik dan lingkungan. Gen-gen yang beragam dari masing-masing galur (varietas) tervisualisasikan dalam karakter-karakter yang beragam pula. Lingkungan memberikan peranan dalam rangka penampakan karakter yang sebenarnya terkandung dalam gen tersebut. Penampilan suatu gen masih labil, karena masih dipengaruhi oleh faktor lingkungan sehingga sering didapatkan tanaman sejenis tapi dengan karakter yang berbeda. Menurut Riani, Amir, Akil, dan Momuat, (2001), setiap tanaman menunjukkan pertumbuhan dan hasil yang beragam sebagai akibat dari pengaruh genetik dan lingkungan, di mana pengaruh genetik merupakan pengaruh keturunan yang dimiliki oleh setiap galur atau varietas sedangkan pengaruh lingkungan adalah pengaruh yang ditimbulkan oleh habitat dan kondisi lingkungan. Perbedaan-perbedaan pada setiap karakter yang diamati (komponen pengamatan) kemungkinan disebabkan oleh adanya perbedaan genetik dari setiap varietas. Faktor genetis tanaman merupakan salah satu penyebab perbedaan antara tanaman satu dengan lainnya. Hal ini disebabkan oleh adanya perbedaan gen yang mengatur karakter-karakter tersebut. Gen-gen yang beragam dari masing-masing varietas divisualisasikan dalam karakter-karakter yang beragam. Namun demikian, dari hasil analisis uji lanjut juga menunjukkan tidak sedikit diantara varietas-varietas tanaman jagung yang digunakan juga mengalami banyak kesamaan karakter yang ditampilkan melalui variabelvariabel yang diamati.

Hasil pengelompokkan varietas berdasarkan tingkat ketahanan terhadap salinitas menunjukkan hasil yang berbedabeda. Varietas Pacakka merupakan verietas yang relatif toleran terhadap salinitas, varietas Arjuna, Bisma, Gumarang, Sukmaraga, Srikandi Kuning merupakan varietas yang mempunyai tingkat ketahanan sedang terhadap salinitas dan varietas Anoman-1 dan Lamuru merupakan varietas yang relatif peka terhadap salinitas. Perbedaan tingkat ketahanan varietas terhadap salinitas diduga dipengaruhi oleh adanya keragaman genetik pada setiap verietas yang digunakan. Hal ini berarti gen yang mengatur karakter ketahanan terhadap salinitas telah menghasilkan keragaman fenotipe yang diekspresikan juga berbeda-beda (Welsh, 1991).

Interaksi Konsentrasi $\mathrm{NaCl}$ dengan Varietas. Hasil analisis statistik menunjukkan bahwa interaksi antara varietas dengan penggunaan konsentrasi $\mathrm{NaCl}$ menunjukkan varietas Pacakka dengan media tanam tanpa pemberian $\mathrm{NaCl}$ menghasilkan jumlah tongkol terbanyak dibandingkan varietas dengan media tanam lainnya. Hasil yang sama secara umum ditunjukkan oleh semua varietas yang ditanam pada media tanam tanpa $\mathrm{NaCl}$. Jumlah tongkol yang terbentuk pada semua varietas semakin berkurang dengan bertambahnya konsentrasi $\mathrm{NaCl}$. Akan tetapi pemberian $\mathrm{NaCl}$ ini sebenarnya tidak menunjukkan pengaruh yang nyata terhadap pembentukan tongkol. Tetapi yang memiliki peranan yang sangat besar dalam hal ini yakni besarnya kandungan air yang terdapat pada media tanam (Jumin, 2002).

Pada beberapa varietas seperti Sukmaraga, Anoman-1, dan Lamuru tidak dapat lagi membentuk tongkol. Sedangkan varietas Arjuna, Bisma, Gumarang, Srikandi Kuning dan Pacakka tetap memperlihatkan kestabilannya dengan tetap membentuk tongkol pada kondisi media tanam dengan kandungan air yang besar. Penampilan dari beberapa varietas yang berbeda dengan kondisi cekaman pertumbuhan yang sama (genangan air) menunjukkan adanya perbedaan genotipe dari beberapa varietas tersebut. Varietas-varietas yang mampu menghasilkan tongkol pada media yang kelebihan air kemungkinan memiliki gen-gen yang mampu mengatur dan kemudian menyebabkan varietas tersebut mampu tetap tumbuh dan menghasilkan tongkol. Menurut Welsh (1991), jika perbedaan antara 2 individu yang mempunyai faktor lingkungan yang sama dapat diukur, maka perbedaan ini berasal dari varietas yang memiliki genotipe yang berbeda.

Hasil analisis statistik selanjutnya tidak menunjukkan terdapatnya interaksi antara 
varietas jagung dan konsentrasi $\mathrm{NaCl}$ pada komponen pengamatanj lainnya. Hal ini diduga akibat penggunaan konsentrasi $\mathrm{NaCl}$ yang terlalu rendah, sehingga kandungan $\mathrm{NaCl}$ yang terdapat di dalam media tanam tidak memiliki pengaruh yang besar terhadap pertumbuhan tanaman akibat kandungan air yang lebih besar. Gen-gen yang terdapat dalam setiap varietas yang mempengaruhi sel-sel tanaman menjadi resisten terhadap cekaman yang pengaruhnya lebih besar meskipun terdapat pengaruh cekaman yang lain seperti terdapatnya $\mathrm{NaCl}$, sehingga gen-gen yang terdapat pada setiap varietas yang resisten tidak mampu untuk bertahan hidup pada kondisi media tumbuh yang kelebihan air. Gen-gen ini mampu mengatur karakter ketahanan terhadap kandungan air yang berlebih sehingga menghasilkan variasi genetik dan dengan sendirinya fenotipe yang diekspresikan juga berbeda. Respon sel berbeda-beda terhadap agen seleksi, karena populasi sel yang heterogen dengan genotipe berbeda, sehingga hanya sel-sel yang resisten yang mampu menampakkan ketahanan terhadap kandungan air yang melebihi kapasitas lapang (Collin dan Dix dalam Dix, 1990). Ismail (1998) menyatakan bahwa respon tanaman terhadap cekaman lingkungan berbeda-beda tergantung genotipe tanamannya. Perbedaan tersebut berkaitan dengan perbedaan toleransi dari setiap genotipe tanaman terhadap cekaman.

\section{KESIMPULAN}

1. Komponen jumlah tongkol memperlihatkan adanya interaksi antara varietas Anoman-1 dan Lamuru dengan konsentarsi $\mathrm{NaCl} 4 \mathrm{~g} \mathrm{~L}^{-1}$ dan $5 \mathrm{~g} \mathrm{~L}^{-1}$ yang digunakan.

2. Varietas Pacakka memberikan tingkat ketahanan terhadap $\mathrm{NaCl} 5 \mathrm{~g} \mathrm{~L}^{-1}$.

3. Konsentrasi $\mathrm{NaCl} 5 \mathrm{~g} \mathrm{~L}^{-1}$ belum dapat dijadikan sebagai batas ketahanan untuk seleksi beberapa varietas jagung.

\section{DAFTAR PUSTAKA}

Blum A. 1988. Plant Breeding for Stress Environment. Florida: CRC Press, Inc. pp 232

Dix PJ. 1990. Plant Cell Line Selection Procedures and Application. Weinheim: VCH. pp 3-18.

Gedoan SP, Indradewa D dan Syukur A. 2004. Tanggapan Varietas Kacang Tunggak Terhadap Cekaman Salinitas. Fakultas Pertanian, Universitas Gadjah Mada. Jurnal Agrosains. vol 17 (1):1

Ismail I. 1998. Peranan Na dan Substitusi Parsial $\mathrm{KCl}$ oleh $\mathrm{NaCl}$ Dalam Pertumbuhan dan Produksi Tebu (Saccharum officinarum L.) Serta Pengaruhnya Terhadap Sifat Kimia Tanah [Disertasi]. Bogor: Program Pasca Sarjana IPB. hal $7-26$.

Jumin HB. 2002. Agroekologi Suatu Pendekatan Fisiologis. Jakarta: Raja Grafindo Persada.

Nasution M. 2006. Diversifikasi Titik Kritis Pembangunan Pertanian Indonesia Pertanian Mandiri. Jakarta: Penebar Swadaya.

Nugraheni IT, Solichatun dan Anggarwulan E. 2003. Pertumbuhan dan Akumulasi Prolin Tanaman Orok-Orok (Crotolaria juncea L.) Pada Salinitas $\mathrm{Cacl}_{2}$ Berbeda. BioSMART. vol 3 (2):1

Riani N, Amir R, Akil M dan Momuat EO. 2001. Pengaruh Berbagai Takaran Nitrogen Terhadap Pertumbuhan dan Hasil Tanaman Jagung Hibrida dan Bersari Bebas. Risalah Penelitian Jagung dan Serealia Lain. vol 5: 21-25.

Sitompul SM dan Guritno B. 1995. Analisis Pertumbuhan Tanaman. Fakultas Pertanian Universitas Gadjah Mada. Yogyakarta: Gadjah Mada University Press.

Teare ID dan Peet MM. 1983. Crop Water Relations. Canada: John Wiley and Sons. pp 211. 